https://doi.org/10.24866/7444-4891-2/283-316

\title{
ГЛАВА 12
}

\section{СТОЙКИЕ ОРГАНИЧЕСКИЕ ЗАГРЯЗНЯЮЩИЕ ВЕЩЕСТВА (СОЗ) В ОРГАНИЗМЕ ЧЕЛОВЕКА: ОПЫТ РОССИИ И БЫВШИХ СОВЕТСКИХ РЕСПУБЛИК}

\author{
Ю.П. Гумовская ${ }^{1}$, А.Н. Гумовский \\ В.Н. Цыганков ${ }^{1,2}$, А.В. Полевщиков
}

В обзоре приведены данные о распространенности и использовании СО3 в России. Описаны актуальные биомониторинговые исследования СО3 в органах и тканях человека. Рассмотрены результаты российских и советских исследований о влиянии ксенобиотиков на человеческий организм. Пик изучения острого воздействия токсикантов на здоровье человека пришелся на 1960-1970 гг. В 1980-1990 гг. появляются работы, изучающие хроническое их воздействие.

Ключевые слова: СОЗ; биомониторинг; здоровье человека; влияние на организм.

${ }^{1}$ Школа биомедицины, Дальневосточный федеральный университет (ДВФУ), 690922, Владивосток, о. Русский, п. Аякс, 10. E-mail: nup1@yandex.ru.

2 Школа естественных наук, Дальневосточный федеральный университет (ДВФУ), 690922, Владивосток, о. Русский, п. Аякс, 10.

3 Отдел иммунологии, Институт экспериментальной медицины (ИЭМ), 197376, СанктПетербург, улица Академика Павлова, 12.

Для цичтирования: Гумовская Ю.П., Гумовский А.Н., Цыганков В.Ю., Полевщиков А.В. Стойкие органические загрязняющие вещества $(\mathrm{CO} 3)$ в организме человека: опыт России и бывших Советских республик // Стойкие органические загрязняющие вещества (CO3) в Дальневосточном регионе: моря, организмы, человек : монография / В.Ю. Цыганков, М.М. Донец, Н.К. Христофорова [и др.] ; науч. ред. В.Ю. Цыганков. - Владивосток : Изд-во Дальневост. федерал. ун-та, 2020. - С. 283-316. https://doi.org/10.24866/7444-4891-2/283-316.

For citing: Gumovskaya Yu.P., Gumovskiy A.N., Tsygankov V.Yu., Polevshchikov A.V. Persistent organic pollutants (POPs) in the human body: the experience of Russia and the ex-USSR republics // Persistent organic pollutants (POPs) in the Far Eastern Region: Seas, Organisms, Human : monograph / V.Yu. Tsygankov, M.M. Donets, N.K. Khristoforova [et al.] ; ed. by V.Yu. Tsygankov. - Vladivostok : Publishing House of the Far Eastern Federal University, 2020. - P. 283-316. - https://doi.org/10.24866/7444-4891-2/283-316. 


\title{
CHAPTER 12. Persistent organic pollutants (POPs) in the human body: the experience of Russia and the ex-USSR republics
}

\author{
Yu.P. Gumovskaya ${ }^{1}$, A.N. Gumovskiy ${ }^{1}$, \\ V.Yu. Tsygankov ${ }^{1,2}$, A.V. Polevshchikov ${ }^{3}$
}

Persistent organic pollutants (POPs) are anthropogenic compounds, which negatively impact on all living organisms and are a global environmental problem. In human body, as a representative of the top of the trophic chain, POPs enter with alimentary, inhalation and contact ways and cause mutagenic, teratogenic and embryotoxic effects. The review data on the prevalence and use of POPs in Russia are presented. The current biomonitoring studies of POPs in human organs and tissues are described. The results of Russian and USSR studies of xenobiotics effect on the human body are considered. The active study of the acute effects of toxicants on human health was in the 1960-1970s. In 1980-1990 publications about chronic impact this compounds are appear.

Key words: POPs; biomonitoring; human health; effect on the body.

\section{Список сокращений:}

ВПР - врожденные пороки развития;

ГН - гигиенические нормативы;

ГХЦГ - гексахлорциклогексан;

ДДЕ - дихлордифенилдихдорэтилен;

ДДТ - дихлордифенилтрихдорэтан;

ЖКТ - желудочно-кишечный тракт;

ЛДГ - лактатдегидрогеназа;

ЛОР - ларингооторинология;

ПДК - предельно допустимая концентрация;

ПХБ - полихлорированные бифенилы;

ПХДД - полихлорированные дибензо-п-диоксины;

$\mathrm{CO} 3$ - стойкие органические загрязняющие вещества;

ХОП - хлорорганические пестициды;

ХОС - хлорорганические соединения;

ЦНС - центральная нервная система. 
В условиях современной цивилизации экологические факторы влияют на здоровье человека на 40-50 \%. Загрязнение окружающей среды одна из основных причин роста заболеваний, приводящих к ослаблению и модификации защитных функций и адаптационных резервов организма человека $[17,24]$. В течение второй половины XX века происходило неконтролируемое загрязнение биосферы продуктами распада пестицидов хлорорганической группы [37].

Пестициды - стойкие органические загрязняющие вещества (CO3), оказывающие повреждающее действие на всех уровнях организации живой материи. Их накопление в окружающей среде представляет глобальную проблему. Вследствие своей токсичности, стабильности в окружающей среде и липофильности они являются общеметаболическими ядами с выраженным побочным мутагенным и канцерогенным действием [56, 76].

Мировое сообщество приняло ряд документов, предусматривающих разработку и осуществление глобальных мер, направленных на уменьшение аккумуляции СО3 в окружающей среде и связанных с ними рисков. В рамках «Конвенции о стойких органических загрязнителях» (Стокгольмская конвенция) ведется глобальный мониторинг уровня СО3 в разных средах обитания, организмах животных, растений и человека, что является предметом широких и многогранных научных проектов [126].

Россия в рамках Стокгольмской конвенции проводит биомониторинг СО3 на всей своей территории. В настоящее время исследованы все звенья морских и наземных трофических уровней [130-133], однако до сих пор остается открытым вопрос о влиянии СО3 на здоровье человека как конечное звено пищевой цепи. Несмотря на значительный объем проводимых в стране исследований $[7,21,26,32,34,52,79,94$, $116,133]$, массив полученных результатов по наличию СО3 на разных уровнях пищевой цепи и в организме человека требует систематизации и обобщения. Дополнительные исследования по-прежнему нужны и для оценки медицинского значения выявленных концентраций СОЗ. В связи с этим цель обзора - систематизация результатов мониторинговых исследований в России с участием человека как биоиндикатора $\mathrm{CO} 3$, а также обобщение данных о возможных патологиях, связанных с воздействием этих ксенобиотиков на организм человека. 


\section{1. Распространенность и использование СОЗ в России}

В России зарегистрировано около 1500 наименований пестицидов, представляющих собой моновещества, их разнообразные композиции, а также препараты биологического действия на основе фитопатогенных штаммов микроорганизмов, грибов и др. [29]. Сведения об основных группах пестицидов обобщены в табл. 12.1.

Таблийа 12.1

\section{Классификация пестицидов по назначению, способу проникновения и характеру действия [104]}

\begin{tabular}{|c|c|}
\hline Группа & Назначение, способ проникновения и характер действия \\
\hline \multicolumn{2}{|r|}{ Инсектицииды } \\
\hline Контактного действия & Вызывают гибель вредных насекомых при контакте \\
\hline Кишечного действия & $\begin{array}{l}\text { Вызывают гибель вредных насекомых при попадании в ки- } \\
\text { шечник }\end{array}$ \\
\hline Системного действия & $\begin{array}{l}\text { Способны продвигаться по сосудистой системе растения и } \\
\text { отравлять поедающих его насекомых }\end{array}$ \\
\hline Фумиганты & $\begin{array}{l}\text { Действуют в газообразном состоянии через органы дыхания } \\
\text { насекомых }\end{array}$ \\
\hline \multicolumn{2}{|r|}{ Гербиичиды } \\
\hline Контактного действия & Вызывают гибель сорных растений при контакте \\
\hline Системного действия & $\begin{array}{l}\text { Способны продвигаться по сосудистой системе растения и } \\
\text { вызывать его гибель }\end{array}$ \\
\hline Почвенного действия & $\begin{array}{l}\text { Действуют на корневую систему растений или на прораста- } \\
\text { ющие семена }\end{array}$ \\
\hline $\begin{array}{l}\text { Избирательного дей- } \\
\text { ствия }\end{array}$ & Поражают только определенные виды растений \\
\hline Сплошного действия & Уничтожают всю растительность \\
\hline \multicolumn{2}{|r|}{ Фунгищиды } \\
\hline Контактного действия & Используют для борьбы с патогенными грибами \\
\hline Системного действия & $\begin{array}{l}\text { Способны продвигаться по сосудистой системе растений и } \\
\text { убивать патогенные грибы }\end{array}$ \\
\hline Защитного действия & Способны защищать от воздействий патогенных грибов \\
\hline Лечебного действия & $\begin{array}{l}\text { Способны давать лечебный эффект при действии патогенных } \\
\text { грибов }\end{array}$ \\
\hline \multicolumn{2}{|r|}{ Другие группь } \\
\hline Ларвициды & Уничтожают личинок и гусениц насекомых \\
\hline Акарициды & Уничтожают растительноядных клещей \\
\hline Овициды & Уничтожают яйца вредных насекомых и клещей \\
\hline Нематоциды & Уничтожают круглых червей \\
\hline $\begin{array}{l}\text { Зооциды, } \\
\text { или родентициды }\end{array}$ & Уничтожают грызунов \\
\hline Моллюстициды & Уничтожают моллюсков \\
\hline Бактерициды & Уничтожают болезнетворные бактерии \\
\hline
\end{tabular}


СТОЙКИЕ ОРГАНИЧЕСКИЕ ЗАГРЯЗНЯЮЩИЕ ВЕЩЕСТВА (СОЗ) В ОРГАНИЗМЕ ЧЕЛОВЕКА: ОПЫТ РОССИИ И БЫВШИХ СОВЕТСКИХ РЕСПУБЛИК

На территории Российской Федерации действует Каталог пестицидов и агрохимикатов, разрешенных к применению Министерством сельского хозяйства РФ. При этом, как видно из табл.4.1, понятие «пестициды» трактуется достаточно широко. К ним относят как средства защиты, так и стимуляторы роста. Все вещества в каталоге зарегистрированы в соответствии с Федеральным Законом № 109 от 19.06.1997 г. «О безопасном обращении с пестицидами и агрохимикатами». В 2018 г. постановлением Главного санитарного врача введены новые Гигиенические нормативы (ГН) 1.2.3539-18 для пестицидов, в то время как до 2016 г. применение пестицидов и химикатов регулировалось ГН 1.2.3111-13 [18].

Многие пестициды уже не применяются в силу низкой эффективности или высокой токсичности, что закреплено в соответствующих международных соглашениях. Тем не менее инвентаризация 2003 г. выявила, что на территории России хранится 24000 т запрещенных к использованию пестицидов и/или средств с истекшим сроком годности. Одновременно дополнительные опасения вызывает тот факт, что 60 \% складов не отвечает санитарным нормам и требованиям безопасности. Масштабное и зачастую бесконтрольное и неоправданное применение пестицидов привело к тому, что на $60 \%$ обследованных территорий отмечается превышение уровней ПДК пестицидов в разных средах. К числу наиболее проблемных территорий относятся регионы самого активного земледелия, вносящие решающий вклад в производство сельхозпродукции в стране, в том числе Краснодарский край (2700 т хранящихся на складах неутилизированных запрещенных к применению или устаревших пестицидов), Ростовская, Воронежская и Курганская области, Алтайский край (до 1000 т в каждом из регионов) [87].

Данные литературы свидетельствуют, что в подавляющем большинстве случаев наиболее загрязненная среда - почва сельхозугодий $[47,105]$. Однако важными дополнительными источниками СО3 могут быть участки лесных пожаров, горящие свалки бытовых отходов и даже небольшие костры на приусадебных и дачных участках [47]. Так, согласно отчету Министерства природных ресурсов и экологии РФ «Состояние загрязнения пестицидами объектов природной среды Российской Федерации» в 2017 г. исследованы почвы различного типа из 39 субъектов РФ. Превышение ПДК по пестицидам обнаружено на территории 11 субъектов Российской Федерации (в 2016 г. - на территории 12 субъектов) [97]. 
Другим важным примером распространенности СО3 в России остаются полихлорированные бифенилы (ПХБ) - один из наиболее распространенных и опасных для окружающей среды и человека классов СО3. Их смеси обладают уникальными физическими и химическими свойствами, обеспечивающими удобство хранения и применения (невоспламеняемость, устойчивость к действию кислот и щелочей, низкая растворимость в воде, широкие диэлектрические характеристики). Именно это определяет их повсеместное использование в промышленности. ПХБ устойчивы к гидролизу и биотрансформации в воде, но со временем при фотолизе в процессе ряда последовательных реакций ПХБ могут стать источником более токсичных соединений - полихлорированных дибензо-п-диоксинов (ПХДД) [71].

Главными источниками загрязнения ПХБ являются многочисленные гидроэлектростанции, железные дороги и промышленные предприятия, производящие и использующие конденсаторы и трансформаторы. Часть ПХБ образуется как побочный продукт в процессе сжигания мусора. В результате проведенной инвентаризации ПХБ и ПХБ-содержащего оборудования в РФ в 2000 г. выявлено наличие около 7500 трансформаторов и 340000 конденсаторов, в которых содержатся около 21000 т ПХБ. Однако, согласно экспертной оценке, реальное количество ПХБ значительно выше и составляет не менее 28000 т [72, 90].

В Советском Союзе, в странах СНГ и Российской Федерации до 2011 г. ПХБ широко использовались в промышленности при производстве трансформаторов. Основные производства находились в городах Серпухов (Россия), Усть-Каменогорск (Казахстан), Гюмри (Азербайджан)), на лакокрасочных заводах в Ярославле, Челябинске, Загорске, Котовске (все - Россия), заводах по изготовлению смазок (Нижний Новгород, Санкт-Петербург, Оренбург, Уфа, Пермь, все - Россия) [42]. В настоящее время наибольшее количество ПХБ обнаружено в Поволжском и Уральском регионах, за ними идут Центральный, Восточно-Сибирский, Северо-Кавказский и ВолгоВятский регионы [64].

С принятием Федерального закона РФ № 164 от 27 июня 2011 года «О ратификации Стокгольмской конвенции о стойких органических загрязнителях (СО3)» Россия взяла на себя обязательства по уничтожению запасов ПХБ. До 2025 г. содержащее ПХБ электротехническое оборудование должно быть выведено из эксплуатации, до 2028 г. - уничтожены со- 
держащие ПХБ отходы. В России контроль выбросов поллютантов в атмосферу осуществляется по специальным программам. Исследование отобранных проб проводится в аккредитованных на проведение анализа диоксинов и ПХБ лабораториях, расположенных в Москве, СанктПетербурге, Обнинске и Уфе [55].

Важной характеристикой токсических эффектов ПХБ является подавление иммунитета. Поступление ПХБ в организм человека также провоцирует развитие рака различной локализации, поражений печени, почек, нервной системы, кожи (нейродермиты, экземы, сыпи). Попадая в организм плода и ребенка, ПХБ проявляют тератогенные эффекты и способствуют появлению врожденных уродств, отставанию в развитии, дисфункции иммунитета, поражению кроветворения. ПХБ также обладают мутагенным действием, что негативно влияет на здоровье последующих поколений.

\section{2. Биомониторинг СО3 в организме человека}

Во многих странах большинство СО3 запрещено или ограничено к применению. В 2006 г. Всемирная организация здравоохранения (ВО3) приняла решение о продолжении применения самого известного хлорорганического пестицида ДДТ в 12 странах мира, в том числе в Индии, Северной Корее и некоторых южноафриканских государствах [126]. Эти CO3 могут попадать в Россию за счет трансграничного переноса, морскими течениями, мигрирующими организмами и с продуктами питания $[120,121]$.

CO3 могут поступать в организм человека алиментарным, ингаляционным и контактным путем через поврежденные и даже неповрежденные кожные покровы. Их воздействию подвергаются как сельские жители, живущие поблизости от мест обработок, так и широкий круг населения вследствие широкого бытового применения [54]. Типичным примером для анализа распространения СО3 в организме человека являются хлорорганические пестициды (ХОП). 
Биологический мониторинг, являющийся интегральным показателем загрязнения накопления ХОП в организме человека, проводится в четырех самых крупных аграрных субъектах Южного Федерального Округа: Краснодарском крае, Астраханской, Волгоградской и Ростовской областях. К сожалению, отсутствуют данные по республикам Адыгея и Калмыкия, земли которых подвергаются процессам природного и антропогенного опустынивания, что уже дало основание признать их зонами экологического бедствия [49, 118, 124].

Кратковременное превышение ПДК пестицидов в 1-2 раза способствует возникновению локальных очагов экологически обусловленных заболеваний $[37,39,74]$. Установлена достоверная прямая связь между заболеваемостью и общей нагрузкой пестицидами на организм человека [36, 123].

С 1998 г. биомониторинг по хлорорганическим соединениям проводится в бывших республиках СССР: Республиках Казахстан [39], Беларусь $[11,34]$, и Армения [92], Украине [22], Кыргызской республике [21, 57, 94]. Имеются данные по биологическому мониторингу Алтайского края [96], Архангельской области [51, 122], Байкальского региона, Иркутской области [52, 53], Дальнего Востока [129, 131, 132, 134], Мурманской (Кольская Лапландия) [23, 25, 28], Орловской [109], Самарской [ 46, 78, $80,125]$ областей, Чукотки [24, 112].

Данные проводимых в настоящее время наблюдений обобщены в табл. 12.2 .

В 1960-1980 гг. были выполнены многочисленные отечественные научно-исследовательские работы, в которых изучалось влияние пестицидов на отдельные органы и системы человека - мозг [3], печень [45, 69], глаза [63], кожу [111], кровь [70], иммунную систему [84, 106], репродуктивную систему $[85,86]$, нервную систему $[9,43]$, вестибулярный аппарат [100], а также на углеводный обмен и окислительные процессы [83].

Высокая растворимость в жирах и низкая растворимость в воде обуславливают задержку ДДТ в жировой ткани. В целом консументы высоких пищевых уровней имеют тенденцию к накоплению больших количеств ДДТ по сравнению с продуцентами и консументами низших пищевых уровней [84]. Отмечается, что в растительной пище диоксинов и ПХБ значительно меньше (растения плохо усваивают липофильные вещества), что прослеживается и при анализе биоматериала людей-вегетарианцев, которые не употребляют животных продуктов [67]. 
СТОЙКИЕ ОРГАНИЧЕСКИЕ ЗАГРЯЗНЯЮЩИЕ ВЕЩЕСТВА (СОЗ) В ОРГАНИЗМЕ ЧЕЛОВЕКА: ОПЫТ РОССИИ И БЫВШИХ СОВЕТСКИХ РЕСПУБЛИК

Таблица 12.2

Концентрация хлорорганических соединений в биологических жидкостях и материалах у жителей разных регионов России и бывших союзных республик

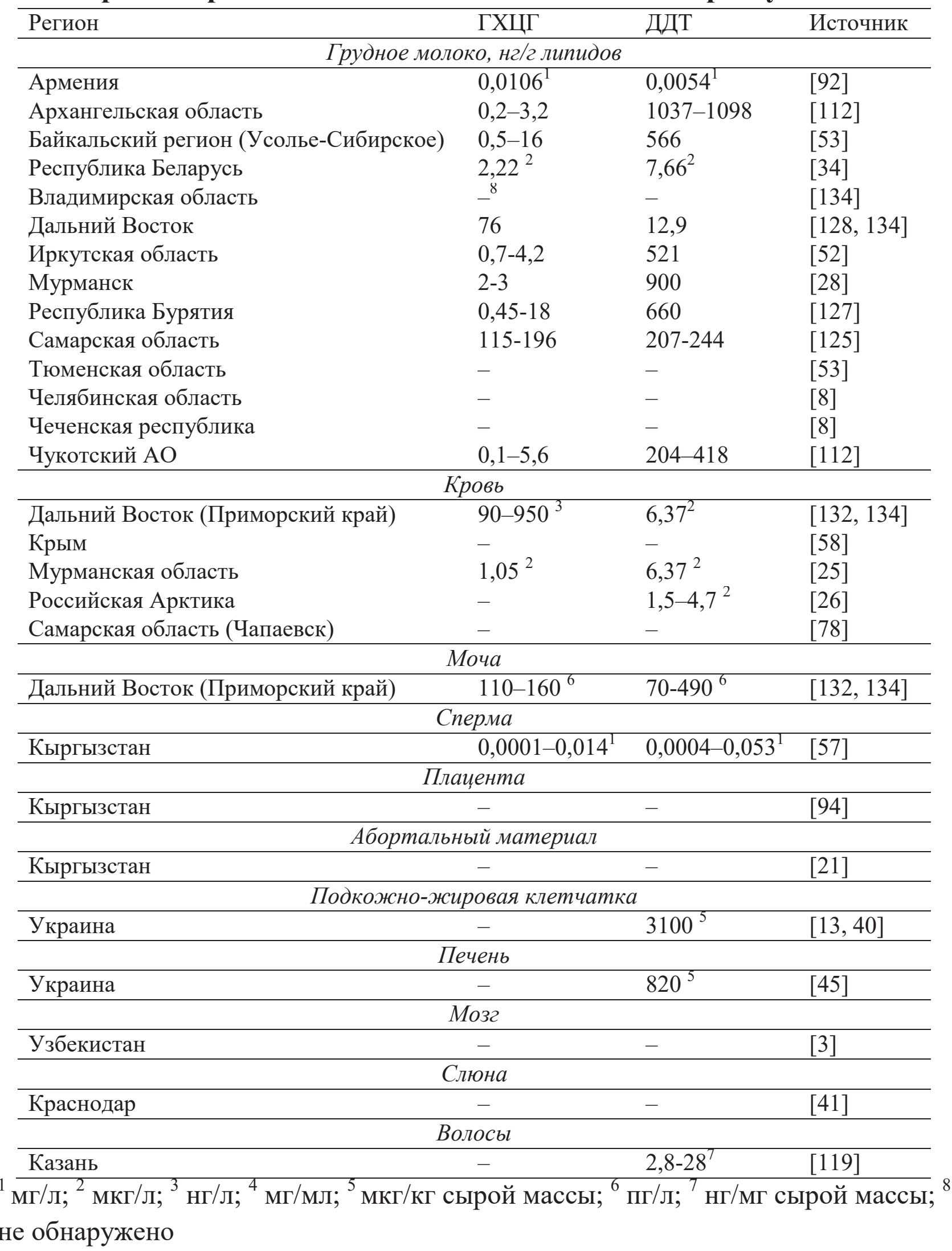


В 2005 г. в Московской медицинской академии им. И.М. Сеченова методами газожидкостной хроматографии и хромато-масс-спектрометрии определено содержание ДДТ и его метаболита ДДЕ в 49 официальных фитопрепаратах (жидких экстрактах и настойках) из травы тысячелистника, чабреца, листьев крапивы, плодов калины и боярышника. Установлено, что абсолютные концентрации ДДТ в жидких экстрактах и настойках достигали 0,45 нг/г, ДДЕ - 3,07 нг/г [20].

Угрозу для здоровья населения может представлять систематическое воздействие поллютантов даже на уровнях, не превышающих гигиенических нормативов. Соответственно, расчет риска для здоровья человека должен охватывать суммарную оценку комплексной нагрузки вдыхаемого загрязненного воздуха, а также поступление веществ с питьевой водой и продуктами питания [31,35].

Из-за невозможности проведения исследования столь широкого спектра объектов существуют рекомендации для анализа СО3 в воздухе, воде, грудном молоке и крови человека [114]. В эпидемиологической практике для оценки степени давности поступления в организм ДДТ обычно используется соотношение 4,4-ДДЕ/4,4-ДДТ в крови и грудном молоке; чем выше этот показатель, тем ниже концентрация исходного 4,4ДДТ и тем дольше длится экспозиция [82].

Для оценки давности поступления пестицидов в экосистему используют отношение концентраций $\alpha$ - и $\gamma$-изомеров ГХЦГ. Значение коэффициента более единицы свидетельствует о давнем присутствии ХОП в среде; значение ниже единицы, т. е. преобладание $\gamma$-изомера, характерно для «свежего» поступления [82]. Относительно большие количества $\beta$-изомера по сравнению с другими ГХЦГ-формами отражают давнее его использование и выраженную биотрансформацию микробиологическим путем [16].

Многолетние наблюдения свидетельствуют также о том, что сывороточные уровни отдельных хлорорганических поллютантов, в частности $\beta$ ГХЦГ, тесно связаны с биомаркерами метаболизма углеводов и липидов, например концентрацией гормона лептина, и степенью инсулинорезистентности среди подростков, проживающих в г. Чапаевске, известном очаге химической опасности [115]. 


\section{3. Российские исследования воздействия СО3 на организм}

Некоторые ученые отмечает выраженную способность СО3 к биоаккумуляции [108]. При их комбинированном воздействии на органы наблюдается простое суммирование содержания $\mathrm{CO}$, которое наблюдалось бы при раздельном поступлении.

Существует много признаков и симптомов хронической интоксикации, которые зависят от пути поступления токсикантов в организм [50]:

- кожные проявления - хлоракне, гиперпигментация, гинеркератоз;

- печеночный синдром - фиброз печени, поражение поджелудочной железы, повышение уровней трансаминазы и триглицеридов в крови, повышенное содержание холестерина, расстройство пищеварения (рвота, тошнота, нарушения стула, непереносимость алкоголя и жирной пищи);

- сердечно-сосудистый синдром - одышка и сердцебиение, миокардиодистрофия, артериальная гипотония;

- респираторный синдром - поражения верхних дыхательных путей, хронический токсический бронхит, который характеризуется диффузной атрофией слизистой оболочки, снижением скоростных показателей вентиляции, повышением вязкостного сопротивления.

\subsection{1. Кожный покров (дерма)}

Хлоракне - известное специфическое повреждение кожи в виде повышенного отложения пигмента, патологического расширения пор и повышенной чувствительности у лиц, имевших контакт с хлорорганическими соединениями [98].

\subsection{2. Сердечно-сосудистая система}

Хроническое воздействие СО3 на организм человека увеличивает частоту и усугубляет течение заболеваний сердечно-сосудистой системы коронарной недостаточности, гипертонической болезни, атеросклероза сосудов [12]. В 1986 г. при исследовании атерогенных свойств СОЗ были отмечены характерные закономерности в нарушении липидного обмена, которые, возможно, ускоряют развитие и отягощают течение атеросклероза [107]. Позже, в 1990 г., эта гипотеза подтвердилась в исследованиях И.Д. Гадалиной: поллютанты вызывают биохимические изменения, харак- 
терные для ранних проявлений атеросклероза, причем меньшая доза ксенобиотика дает более выраженный атерогенный эффект [15].

CO3 обладают прямым положительным инотропным действием на миокард [4, 10]. Согласно биохимическим исследованиям установелен рост активности ЛДГ (лактатдегидрогеназа) в миокарде на 90-й день интоксикации СО3 и уменьшение уровня ЛДГ в сыворотке крови, что свидетельствует об определенных нарушениях и перестройке биоэнергетических процессов в кардиомиоцитах. Повреждение митохондриальных мембран (как наружных, так и внутренних) влечет за собой нарушения окислительного фосфорилирования, утилизации АТФ миофибриллами и др. Эти изменения, в свою очередь, приводят к снижению энергии сокращения миофибриллярного аппарата, нарушению возбуждения, связанного с сокращением и расслаблением миокарда. Энергетическая недостаточность компенсируется за счет развития гигантских форм митохондрий, гипертрофии миофибрилл [107].

\subsection{3. Нервная система}

Поражения нервной системы характерны для действия всех СО3. При хронических отравлениях наблюдаются разнообразные функционально-динамические нарушения со стороны нервной системы: диффузное поражение (энцефалополиневропатия) с рассеянными мелкоочаговыми органическими симптомами; полный симптомокомплекс вегетативно-астенического синдрома в виде снижения работоспособности, бессонницы, повышенной раздражительности, лабильности артериального давления, гипергидроза, гиперрефлексии и других расстройств. Наиболее тяжелые патологические изменения при отравлении хлорорганическими ядохимикатами возникают в структурах ЦНС, которые во многом сходны с клиникой энцефалита с преимущественным поражением подкорковой области [4]. При тяжелых формах интоксикации может развиться гипоталамический синдром (гипергликемия, артериальная гипертония, ожирение) [4].

Следует учитывать, что некоторые СО3 обладают отдаленным нейротоксическим действием. Исследования когнитивных функций населения, проживающего в экологически неблагополучных трех поселках Талгарского района, показали, что почти 70 \% жителей имели низкий уро- 
СТОЙКИЕ ОРГАНИЧЕСКИЕ ЗАГРЯЗНЯЮЩИЕ ВЕЩЕСТВА (СОЗ) В ОРГАНИЗМЕ ЧЕЛОВЕКА: ОПЫТ РОССИИ И БЫВШИХ СОВЕТСКИХ РЕСПУБЛИК

вень устойчивости и концентрации внимания при усвоении информации, значительное и существенное снижение работоспособности из-за доминирования процесса торможения в ЦНС, что характерно для переутомления или астенизации организма [39].

\subsection{4. Иммунная система}

Стойкое подавление активности иммунной системы свойственно большинству ксенобиотиков. Этот эффект отмечается даже при действии низких малотоксичных доз [99]. Доказано отрицательное влияние СО3 на иммунную систему человека, ведущее к атипичному течению различных инфекционных и неинфекционных заболеваний, сопровождающихся повышением риска развития аутоиммунных патологий $[65,99]$.

При интоксикации поллютантами наблюдается лимфопения, затрагивающая все классы лимфоцитов (Т-, В-, NK-клетки). На протяжении четырех месяцев и более сохраняются изменения иммунитета после кратковременного контакта с ксенобиотиками. При длительном воздействии пестицидов нарушения в иммунной системе сохраняются в течение 2-10 лет [99].

В работах М. Исраилова [38] показано, что у лиц, проживающих в зонах активного применения пестицидов, выявляются стойкие и глубокие нарушения иммунной системы, приводящие к развитию затяжной пневмонии. Соответственно, патологии респираторной системы являются индикаторами экологически неблагополучной воздушной среды [66].

Многолетние международные исследования в Арктическом регионе убедительно доказали развитие иммунодефицитных состояний, вызванных отравлением СО3 взрослого населения, в рационе которого присутствуют рыба и мясо морских животных. Страдают также грудные дети, получающие токсиканты с молоком матери [113].

\subsection{5. Выделительная система}

В районах интенсивного применения СО3 чаще регистрируются нарушения функционального состояния почек в форме снижения клубочковой фильтрации и угнетения азотовыделительной функции. Многократно возрастают дисметаболические нефропатии, чаще встречаются аномалии органов мочевой системы, патологические изменения биохимических 
показателей мочи [148]. Частота инфекционно-воспалительных заболеваний почек в зонах интенсивного применения пестицидов или непосредственного контакта с ними - 12,5\%, в зоне средней интенсивности применения $-7,9 \%$, в «чистых» зонах $-1,6 \%[6,48]$. При клинико-эпидемиологическом исследовании проживающих в регионах использования пестицидов были выявлены признаки острых инфекционно-воспалительных заболеваний почек с тяжёлым течением в 6,5\% случаев [88].

Гистологические и цитоэнзиматические изменения в структурах нефронов позволяют предполагать проникновение пестицидов внутрь эндотелия капилляров клубочков в процессе фильтрации крови и в эпителий канальцев при реабсорбции ультрафильтрата. При этом большее нефротоксическое воздействие оказывает ГХЦГ, связанное с выраженным угнетением ферментов, участвующих в фильтрационно-реабсобционносекреторных процессах в нефронах [77].

\subsection{6. Репродуктивное здоровье мужчин}

Интерес к поиску взаимосвязи между СО3 и мужским бесплодием вызван тем, что практически все антропогенные поллютанты дают гонадои эмбриотоксический эффект, связанный с наличием у них гормоноподобных свойств, которые получили название «гормоноподобные ксенобиотики» (ГПК), или «гормоны внешней среды» [61, 62]. Многие исследователи связывают мужское бесплодие с действием пестицидов, в частности ДДТ [59]. В зонах, загрязненных СО3, заболеваемость мужским бесплодием в 2-2,5 раза (первичным мужским бесплодием - на 8-10\%) выше, чем в экологически чистых зонах. ХОП из спермы у больных мужским бесплодием выявлены в 75,4\% случаев против $4,3 \%$ в контроле. Заболеваемость бесплодием коррелирует с содержанием в сперме СО3, что может быть одной из причин мужского бесплодия [95].

Медленные темпы выведения СО3 способствуют увеличению концентрации этих веществ с возрастом. Однако выведение ксенобиотиков у мужчин и женщин различно [81]. В организме мужчин в течение жизни накапливается больше СО3. А. А. Дударев отмечает более высокое содержание ХОС в крови мужчин по сравнению с женщинами тех же возрастных групп [27]. Это может быть связано с присутствием в рационе мужчин большего количества мяса и рыбы, а также с тем, что женский орга- 
СТОЙКИЕ ОРГАНИЧЕСКИЕ ЗАГРЯЗНЯЮЩИЕ ВЕЩЕСТВА (СОЗ) В ОРГАНИЗМЕ ЧЕЛОВЕКА: ОПЫТ РОССИИ И БЫВШИХ СОВЕТСКИХ РЕСПУБЛИК

низм может частично выводить ХОС с грудным молоком и частично передавать запасенные вещества потомству [130, 132].

При воздействии СО3 на организм мужчин нарушаются процессы сперматогенеза [57, 93]. По мере возрастания загрязнения повышается процент патоспермии, причем количество пациентов с полным отсутствием в эякуляте сперматозоидов (азооспермия) увеличивается практически в пять раз.

\subsection{7. Пищеварительный тракт}

Отмечается, что для многих токсичных веществ гематосаливарный барьер не становится препятствием. Выявлена прямая связь содержания пестицидов в сыворотке крови и ротовой жидкости для $\alpha$-ГХЦГ и $\gamma$ ГЦХГ. Дальнейшие сравнительные исследования показали, что слюна околоушной железы содержит названные изомеры в более высокой концентрации, чем ротовая жидкость, и коррелирует с концентрацией пестицида в сыворотке с более высоким коэффициентом корреляции. Также в смешанной слюне были обнаружены ДДТ и его метаболиты [41]. Одновременно у жителей сельских районов, подвергающихся выраженному воздействию пестицидов, диагностировали наличие кариеса в 78,3\%, пародонтоза - 82,2\%, стоматита - 62,7\%, патологической стираемости зубов в 22,2\%, в контрольном районе указанные заболевания были выявлены в $48,3,15,4,6,4$ и 0\% соответственно [30].

Действие $\mathrm{CO} 3$ на печень способно привести к развитию токсического гепатита. Токсический гепатит нарушает состав желчи и вызывает синдром холестаза. Возможно также развитие токсического панкреатита. Повреждение поджелудочной железы связано с повышением давления в системе панкреатических протоков вследствие дискинезии желудочнокишечного тракта (ЖКТ) и дистонии сфинктера Одди [66].

3.M. Омарова предположила определенные механизмы воздействия СО3. Прямое повреждающее действие на слизистую оболочку ЖКТ приводит к воспалительным и эрозивно-язвенным изменениям. Повреждение слизистой оболочки ведет к нарушению моторики, развивается дискинезия желудка, кишечника и желчевыводящих путей. Дистония сфинктера Одди приводит к нарушению оттока секрета от поджелудочной железы. Следующий механизм вовлечения ЖКТ в патологический процесс - воз- 
действие СО3 непосредственно на нервную систему с развитием вегетативных расстройств и нарушений моторики органов пищеварения [66].

\subsection{8. Онкологические заболевания}

Период максимального применения СО3 (1980-1995 гг.) показал, что с насыщением окружающей среды пестицидами растет количество онкологических заболеваний [1].

Исследования, проведенные в Курской области [2], свидетельствуют о наличии связи между ростом заболеваемости раком желудка и молочной железы и количеством вносимых в почву пестицидов. В другом регионе, в условиях сельской местности юга Кыргызстана, одной из главных причин развития рака молочной железы у много рожавших являются ХОП [68]. На основании полученных фактов было предложено считать частоту рака молочной железы чувствительным критерием загрязнённости окружающей среды пестицидами [17]. В различных районах Таджикистана анализ распространенности острой лейкемии показал, что ведущим фактором в развитии этой патологии стало масштабное использование химических удобрений [60]. Занятость родителей в сельском хозяйстве, сопряженная с производственным контактом с пестицидами, также может повышать риск развития онкологических заболеваний у детей [89].

\subsection{9. Репродуктивное здоровье жсенщин и беременность}

Изменения показателей репродуктивного здоровья отражают состояние среды обитания, характеризуя мутагенность и эмбриотоксичность факторов и их способность подавлять адаптационные механизмы организма [44]. О значительных изменениях здоровья беременных женщин, проживающих в условиях воздействия загрязненной окружающей среды, сообщается в Челябинской (Челябинск, Магнитогорск, Карабаш), в Свердловской областях (Кировград, Нижний Тагил), страдает здоровье женщин, проживающих вблизи химических заводов в Тамбовской, Иркутской и других областях $[5,26,94]$.

Изучение влияния комбинированных пестицидов на репродуктивную функцию женщин, работавших в цехах протравителей семян, показало, что осложнения беременности встречались в 3,5 раза чаще, чем в контрольной группе. При гистологическом исследовании в плаценте обнару- 
живаются деструктивные изменения (инфаркты, облитерация сосудов и пр.), снижающие ее функциональные возможности, что становится одной из причин перинатальной патологии [14].

Контакты беременных женщин с пестицидами увеличивают частоту осложнений беременности и родов, вызывают мертворождаемость, аномалии у новорожденных, ведут к ухудшению комплексных показателей состояния здоровья детей $[98,110]$. У 100\% исследованных беременных женщин Украины обнаружили ДДТ в периферической крови в концентрациях от 0,28 (в Полтаве) до 6 мкг/л (в Киеве) [22]. Наиболее тяжелые осложнения при беременности, родах и в послеродовом периоде выявлены при обнаружении алдрина и ДДТ [98].

ХОП способны проходить через плацентарный барьер [83, 103]. Изучения мертворожденных выявили среднее содержание ДДТ в подкожно-жировой ткани плода (3100 мкг/кг), что мало отличалось от содержания его в подкожно-жировой клетчатке оперированных взрослых людей (4330 мкг/кг) [40]. В печени мертворожденных детей концентрация ДДТ составляла в среднем 820 мкг/кг [41]. ГХЦГ также преодолевает плацентарный барьер [126]. Пестициды увеличивают высвобождение катехоламинов из синаптических нервных окончаний, проникают через плацентарный барьер, вызывая структурно-метаболические нарушения в тканях плаценты, оказывая токсическое действие на плод и провоцируя выкидыши [102].

В Кыргызской Республике у 39,2\% беременных женщин из плаценты выявили ХОП, концентрация которого достигала 2,27 мг/кг. Чем выше содержание ХОП в плаценте, тем чаще отмечалась патология у беременных. Установлена корреляция между обнаружением ХОП в плацентах и гинекологическими осложнениями в послеродовом периоде [94].

В 30,5\% случаев в абортальных материалах, полученных после прерывания беременности (в первые два месяца до образования плаценты), обнаружено наличие ксенобиотиков, в 5,33\% - выявлена высокая концентрация хлорорганических пестицидов, в 2,66\% - патология эмбриона (врожденные пороки) (табл. 12.3) [21].

Четкие различия выявлены и после родов. Если в крови женщин обнаруживался ГХЦГ, то процент асфиксии новорожденных возрастал вдвое (12,0\%). У первородящих (с ГХЦГ в крови) рождалось значительно больше детей с аномалиями развития (2,56\% при 0,15\% в контроле) [101]. 


\section{Содержание пестицидов}

в исследуемых абортальных материалах [21]

\begin{tabular}{llll}
\hline Концентрация ХОП в & Количество & \multicolumn{2}{l}{ Из них обнаружен ХОП } \\
\cline { 4 - 5 } абортальном материале & обследованных & Количество \% \\
\hline Всего обследовано & 75 & 23 & 30,6 \\
Из них ХОП в пределах 0,1 мг/кг & 75 & 4 & 5,33 \\
Из них обнаружено ВПР & 75 & 2 & 2,66 \\
Из них ХОП свыше 0,1 мг/кг & 75 & 17 & 22,6 \\
\hline
\end{tabular}

Высокие уровни поллютантов вызывают негативные сдвиги в демографической ситуации. Так, с увеличением пестицидных нагрузок растет смертность ( $\mathrm{r}=0,82, \mathrm{p}<0,05)$, а рождаемость падает $(\mathrm{r}=-0,67, \mathrm{p}=0,046)$ [108].

Наиболее чувствительным индикатором оценки состояния здоровья популяции, влияния на него факторов внешней среды являются показатели здоровья новорожденных, в частности, распространенности врожденных пороков развития. Доказано, что врожденные патологии связаны с влиянием хлорорганических пестицидов на беременных и женщин детородного возраста [21]. Уровень первичной заболеваемости детей врожденными аномалиями, болезнями органов пищеварения, эндокринной системы коррелирует с площадью обработки пашни пестицидами и минеральными удобрениями в регионе [102]. Для уменьшения поступления пестицидов М. Х. Хамидов [101] рекомендовал удлинить интервал между беременностями до трех лет, говоря о «желательности наступления зачатия в зимний и весенний периоды года».

\subsubsection{0. Грудное молоко}

Особую проблему педиатрии составляет риск остаточного содержания пестицидов в продуктах питания, особенно детского. Чем младше ребенок, тем больше относительная доза пестицида, которую он получает в равных со взрослыми условиях [66].

В районах с повышенными показателями СО3 возрастает число детей с заболеваниями ЛОР-органов (хронический фарингит, трофический ринит, синусит, ларингит, ангина и хронический тонзиллит, отит). Рост воспалительных заболеваний среднего уха отмечается у детей эскимосов, питающихся молоком матерей, а также морской рыбой и мясом морских животных, содержащими повышенные концентрации пестицидов [113]. 
Грудное молоко как объект наблюдения имеет ряд преимуществ, поскольку отбор проб представляет собой неинвазивный метод, не связанный с техническими и инструментальными сложностями. Уровни СО3 в грудном молоке считаются индикатором их нагрузки на материнский организм [73]. У матерей, в грудном молоке которых был обнаружен ДДТ, чаще рождались дети малого веса и недоношенные $(26,5 \pm 2,7 \%)$, чем у матерей, в молоке которых этот ксенобиотик не обнаружен $(13,1 \pm 3,7 \%)$ [3]. Это подтверждено исследованиями И. А. Застенской с соавт. [33], которые показали выраженную отрицательную зависимость между степенью загрязнения грудного молока ДДТ и весом ребенка при рождении.

Выявлено высокое содержание ДДТ в грудном молоке жительниц Казахстана, что в целом характерно для бывших республик СССР [18, 19]. При мониторинге ХОП в пробах грудного молока рожениц республики Армения частота обнаружения основных загрязнителей ( $\gamma$-изомер ГХЦГ и ДДЕ) составляла $100 \%$; частота определения ДДТ увеличилась по сравнению с 2009 г. и составила 71,4\%. При этом обнаруживаемые остаточные количества ХОП оказались на порядок и выше, чем в 2009 г.: $\gamma$-изомер ГХЦГ - 0,0147 мг/л; ДДЕ - 0,0169 мг/л; ДДТ - 0,0039 мг/л [91].

У новорожденных, питающихся грудным молоком, суточная доза ПХБ может в 10-100 раз превышать таковую у их матерей. Для новорожденных, метаболические потенции которых еще не столь развиты, основным механизмом удаления ПХБ из организма является регулярный «жирный стул» [117].

Е. А. Мамонтова с соавт. [52] отмечают, что на уровень содержания ПХБ в грудном молоке влияет диета матери. Традиционно население поселков на берегах Байкала использует в своем рационе жир нерпы и голомянки. Концентрации ПХБ в их жире намного выше, чем в промысловых видах рыб. В грудном молоке жительниц побережья оз. Байкал уровень ПХБ сравним только с уровнями ПБХ в молоке жительниц Фарерских островов, в основной рацион которых входят жир и мясо морских рыб, млекопитающих и птиц, а также жительниц г. Серпухова, работавших на трансформаторном заводе, где в производстве использовалась техническая смесь ПХБ (совол), а также жительниц Фарерских островов, в рацион которых входит жир и мясо морских рыб, млекопитающих и птиц. 


\section{4. Заключение}

Человек находится в верхней части пищевой цепи, поэтому именно он подвергается наибольшей опасности воздействия СОЗ. В связи с этим оценка влияния ксенобиотиков на здоровье населения по-прежнему актуальна [79].

Пестициды, поступающие в организм человека по миграционным и транслокационным цепочкам, могут оказывать мутагенное действие, увеличивать количество точечных мутаций и хромосомных аберраций в соматических и половых клетках, приводить к развитию новообразований, спонтанным абортам и перинатальной гибели плода, врожденным аномалиям, бесплодию [34]. Согласно сложившейся практике, оценка мутагенности пестицидов основана на определении мутагенных свойств отдельных действующих компонентов, входящих в состав их препаративных форм. Вопрос о дополнительном исследовании препаративных форм, включающих несколько действующих веществ, представляется крайне актуальным [75].

Пик изучения острого воздействия пестицидов на здоровье человека пришелся на 1960-1970 годы ХХ века. В 1980-1990 гг. появляются работы, изучающие хроническое их воздействие. В последние годы число их резко снизилось. Сегодня в городах России биомониторинговые исследования либо не проводятся, либо проводятся непостоянно, что не дает полной картины по стране. Также практически нет новых публикаций о влиянии СО3 на здоровье населения с применением современных методов [80].

Таким образом, существует необходимость разработки и введения на законодательном уровне системы постоянного государственного биомониторинга, включающего анализ окружающей среды, живых организмов и человека как биоиндикатора аккумуляции, биотрансформации и долговременных эффектов СО3. 


\section{5. Список литературы}

1. Абдуллаев, Р.Б. Аральский кризис: проблемы экологической культуры и здоровья / Р.Б. Абдуллаев, Ш.Б. Дусчанов, Д.С Маткаримова [и др]. - Ургенч, 2012. - 120 с.

2. Адамович, В.Л. Экологическая тактика применения пестицидов в сельском хозяйстве и пути предупреждения вредных последствий / В.Л. Адамович. - Брянск, 1986. - 215 с.

3. Азизова, О.М. Морфологические изменения в головном мозге при хронической интоксикации пестицидами: автореф. дис. ... д-ра. мед. наук / О.М. Азизова. - Самарканд, 1981. - 34 с.

4. Азовскова, Т.А. Профессиональные интоксикации пестицидами / Т.А. Азовскова, Н.В. Вакурова, Н.Е. Лаврентьева. - Самара: ООО «СамЛюксПринт», 2014. - 78 с.

5. Айламазян, Э.К. Влияние экологической обстановки на репродуктивное здоровье женщины. Новый взгляд на проблему / Э.К. Айламазян, Т.В. Беляева, Е.Г. Виноградова // Вестник Российской ассоциации акушеров-гинекологов. - 1996. - № 2. - С. 13-16.

6. Аллазов, С.А. Острые инфекционно-воспалительные заболевания почки в условиях воздействия пестицидов (клинико-экспериментальное исследование): автореф. дис. ... докт. мед. наук / С.А. Аллазов. - Москва, 1992. -28 c.

7. Амирова, 3.К. Новые стойкие органические супертоксиканты и их влияние на здоровье человека / 3.К. Амирова, О.А. Сперанская, Ш.Н. Галимов. - Москва, 2016. - 169 с.

8. Амирова, З.К. Содержание ПХДД/Ф и ПХБ-ВОЗ в плазме крови и грудном молоке жителей Чеченской республики / З.К. Амирова, И.Я. Шахтамиров // Юг России: экология, развитие. -2012. - № 2. - С. 125-129.

9. Атабаев, Ш.Т. Гигиеническое изучение объектов внешней среды при применении пестицидов в условиях жаркого климата и оздоровительно-профилактические мероприятия: дис. ... докт. мед. наук / Ш.Т. Атабаев. - Ташкент, 1967. - 44 с.

10. Ахмедов, Б.Х. Показатели периферической крови у крыс при хронической интоксикации пестицидами / Б.Х. Ахмедов, К.К. Салиев // Медицинский журнал Узбекистана. - 2000. - № 3. - С. 89-90.

11. Баркатина, Е.Н. Содержание остаточных количеств хлорорганических пестицидов в основных продуктах питания, грудном молоке и жи- 
ровой ткани жителей Беларуси / Е.Н. Баркатина, А.Л. Перцовский, В.И. Мурох // Хранение и переработка сельхозсырья. - 2002. - № 7. С. 29-32.

12. Бойкулов, М.Ч. Сравнительная характеристика аорты крыс в норме и при воздействии пестицидов / М.Ч. Бойкулов // Морфология. 2004. - № 4. - С. 22.

13. Васьковская, Л.Ф. Химико-биологическая характеристика накопления и распределения ДДТ в организме человека: дис. ... канд. биол. наук / Л.Ф. Васьковская. - Киев, 1971. - 192 с.

14. Вержанский, П.С. Влияние комбинированных пестицидов (фентиурам, хомецин и др.) на репродуктивную функцию и профилактика осложнений у женщин, работающих на химическом предприятии: автореф. дис... канд. мед. наук / П.С. Вержанский. - Харьков, 1979. - 22 с.

15. Гадалина, И.Д. Некоторые методические подходы к оценке кардиотоксического эффекта пестицидов с учетом возрастного фактора / И.Д. Гадалина // Гигиена и санитария. -1990. - № 7. - С. 77-78.

16. Галиулин, Р.В. Эколого-геохимическая оценка “отпечатков" стойких хлорорганических пестицидов в системе почва-поверхностная вода / Р.В. Галиулин, Р.А. Галиулина // Агрохимия. - 2008. - № 1. - С 52-58.

17. Гичев, Ю.П. Загрязнение окружающей среды и экологическая обусловленность патологии человека / Ю.П. Гичев // Экология. Серия аналитических обзоров мировой литературы. - 2003. - № 68. - С. 1-138.

18. ГН 1.2.3111-13 "Гигиенические нормативы содержания пестицидов в объектах окружающей среды (перечень)" (с изменениями на 13 июля 2016 года). - М.: Федеральный центр гигиены и эпидемиологии Роспотребнадзора, 2014. - 131 с.

19. Гончарук, Е.И. Использование системы мать-плод-новорожденный для изучения комбинированного действия пестицидов и других химических веществ / Е.И. Гончарук, Г.И. Сидоренко, М.В. Голубчиков, А.С. Прокопович // Гигиена и санитария. - 1990. - № 6. - С. 4-7.

20. Гравель, И.В. Оценка перехода ДДТ и его метаболитов в жидкие экстракты и настойки из лекарственного растительного сырья / И.В. Гравель // Традиционная медицина. - 2005. - № 1. - С. 28-31.

21. Дарбишев, Э.П. Влияние хлорорганических пестицидов на рождаемость детей с врожденной патологией в Ошской области / Э.П. Дарбишев, А.М. Ешиев // Актуальные проблемы и достижения в медицине: 
сборник научных трудов по итогам международной научно-практической конференции. - Самара: Инновационный центр развития образования и науки, 2017. - С. 96-99.

22. Демченко, В.Ф. Гигиенические аспекты биомониторинга хлорорганических пестицидов: дис. ... канд. биол. наук / В.Ф. Демченко. Киев, 1989. - 332 с.

23. Дударев, А.А. Специфика экспозиции к дихлородифеиилтрихлорэтану коренных жителей прибрежной и материковой Чукотки / А. А. Дударев, В. С. Чупахин, 3. С. Иванова, Г. Б. Лебедев // Гиена и санитария. 2012. - № 2. - C 15-20.

24. Дударев, А.А. Здоровье человека в связи с загрязнением Арктики - результаты и перспективы международных исследований под эгидой АМАП / А.А. Дударев, Й.О. Одланд // Экология человека. - 2017. - № 9. C. 3-14.

25. Дударев, А.А. Особенности экспозиции к полихлорированным бифенилам коренных жителей прибрежной и материковой Чукотки / А.А. Дударев, В.С. Чупахин, 3.С. Иванова, Г.Б. Лебедев // Гигиена и санитария. - 2012. - № 4. - С. 22-28.

26. Дударев, А.А. Оценка влияния экспозиции к стойким токсичным веществам на исход беременности, соотношение полов новорожденных и менструальный статус коренных жительниц Чукотки / А.А. Дударев, В.С. Чупахин // Гигиена и санитария. - 2014. - № 1. - С. 36-40.

27. Дударев, А.А. Персистентные полихлорированные углеводороды и тяжелые металлы в Арктической биосфере: основные закономерности экспозиции и репродуктивное здоровье коренных жителей // Биосфеpa. - 2009. - № 2. - С. 186-202.

28. Дударев, А.А. Уровни экспозиции к стойким органическим загрязнителям (СО3) населения Печенгского района Мурманской области / А.А. Дударев, Е.В. Душкина, Ю.Н. Сладкова, В.С. Чупахин Л.А. Лукичева // Токсикологический вестник. - 2016. - Т. 3. - С. 2-9.

29. Ежегодник «Состояние загрязнения пестицидами объектов природной среды Российской Федерации в 2016 году». - Обнинск: ФГБУ «НПО «Тайфун»», 2017. - 80 с.

30. Жуматов, У. Состояние органов полости рта при воздействии на организм хлор- и фосфорорганических пестицидов: автореф. дис. ... канд. мед. наук / У. Жуматов. - Ташкент, 1982. - 46 с. 
31. Журба, О.М. Социально-гигиенические аспекты определения остаточных количеств хлорорганических пестицидов в пищевой продукции / О.М. Журба, Н.А. Тараненко // Бюллетень ВСНЦ СО РАМН. - 2007. № $1 .-$ С. 56-58.

32. Застенская, И.А. Изучение влияния полихлорированных бифенилов и тяжелых металлов на показатели иммунной системы в эксперименте / И.А. Застенская, Н.П. Пивень, В.В. Кочубинский, А.В. Кочубинский // Токсикологический вестник. - 2014. - № 2. - С. 28-31.

33. Застенская, И.А. Потенциальная роль эпидемиологический исследований и биологического мониторинга в гигиеническом нормировании / И.А. Застенская, В.В. Кочубинский // Актуальные проблемы транспортной медицины. - 2010. - № 2 (20). - С. 90-94.

34. Застенская, И.А. Хлорорганические пестициды: биологический мониторинг и мониторинг окружающей среды в оценке воздействия на здоровье новорожденных / И.А. Застенская // Здоровье и окружающая среда. - 2009. - № 14. - С. 540-547.

35. Захаренков, В.В. Определение приоритетности природоохранных мероприятий на основе оценки риска для здоровья населения промышленного города / В.В. Захаренков, В.В. Кислицына // Успехи современного естествознания. - 2014. - № 2. - С. 12-15.

36. Иванов, А.В. Состояние здоровья населения на территориях интенсивного применения пестицидов / А.В. Иванов, В.В. Васильев // Гигиена и санитария. - 2005. - № 2. - С. 24-27.

37. Инелова, 3.А. Фитоценозная биоиндикация загрязненных пестицидами почв (Талгарский район Алматинская область) / З.А. Инелова, А.А. Нуржанова, Р.Д. Жамабалинова [и др.] // Вестник КазНУ. Серия экологическая. - 2010. - Т. 29. - № 3. - С. 29-33.

38. Исраилова, М. Клинико-иммунологические особенности течения и лечения затяжных пневмоний у больных, проживающих в зоне применения пестицидов: автореферат дис. ...канд.мед.наук / М. Исраилова. Москва, 1992. - 19 с.

39. Капышева, У.Н. Влияние многолетнего пестицидного загрязнения окружающей среды на здоровье человека / У.Н. Капышева, Ш.К. Бахтиярова, Б.И. Жаксымов // Международный журнал прикладных и фундаментальных исследований. - 2019. - № 3. - С. 56-60.

40. Комарова, Л.И. Носительство ДДТ и некоторые стороны его влияния на организм: дис. ... канд. мед. наук / Л.И. Комарова - Киев, 1969. - 12 с. 
41. Коротько, Г.Ф. Саливадиагностика - ренессанс неинвазивных технологий // Кубанский научный медицинский вестник. - 2006. - № 9. C. 145-149.

42. Корпакова, И.Г. Содержание стойких хлорорганических пестицидов и полихлорбифенилов в акватории лицензионного участка ООО «НК «Приазовнефть» в Азовском море / И.Г. Корпакова, Л.И. Короткова, А.А. Ларин [и др.] // Защита окружающей среды в нефтегазовом комплекce. -2015 . - № 11. - С. 48-54.

43. Краснюк, Е.П. Клиника и лечение хронических интоксикаций у рабочих производства ДДТ: дис. ... канд. мед. наук / Е.П. Краснюк. - Киев, 1961. - $16 \mathrm{c}$.

44. Кузмин, Д.В. Сравнительный анализ репродуктивного здоровья женщин, проживающих в районах расположения алюминиевого производства / Д.В. Кузмин // Гигиена и санитария. - 2007. - № 3. - С. 13-15.

45. Кузьминская, У.А. Биохимическая характеристика субклеточных культур печени при воздействии пестицидов: (К механизму действия хлорорганических и карбаматных пестицидов): автореф. дис. ... д-ра мед. наук / У.А. Кузьминская. - Киев, 1975. - 42 с.

46. Лазарева, Н.В. Взаимозависимые патогенетические риски влияния экотехнологических факторов на соматическое и репродуктивное здоровье человека / Н.В. Лазарева, О.И. Линева // Медицинский альманах. 2017. - № 6 (51). - С. 63-68.

47. Ларионов, К.В. Распространение пестицидов в экосистеме Краснодарского края и минимизация их воздействия на окружающую среду: автореф. дис. ... канд. хим. наук / К.В. Ларионов. - Краснодар, 2008. - 22 с.

48. Латыпова, Р.И. Функциональное состояние почек у лиц, работающих с комплексом хлор- и фосфорорганических пестицидов / Р.И. Латыпова // Медицинский журнал Узбекистана. - 1971. - № 11. - С. 19-23.

49. Лидерман, Е.М. Анализ экологических условий обусловленности здоровья населения Южного Федерального округа в аспекте организации региональной системы медико-социальной реабилитации / Е.М. Лидерман, М.В. Забелин // Здравоохранение, образование и безопасность. 2018. - №1 (13). - С. 7-20.

50. Лотков, В.С. Клинико-патогенетические особенности хронического воздействия хлорированных углеводородов на органы дыхания и другие системы организма (экспериментально-клиническое исследование): автореф. дисс... докт. мед. наук / В.С. Лотков. - Самара, 2000. - 38 с. 
51. Лыжина, А.В. Химическое загрязнение продуктов питания и его влияние на здоровье населения Архангельской области / А.В. Лыжина, Р.В. Бузинов, Т.Н. Унгуряну, А.Б. Гудков // Экология человека. - 2012. № 12. - C. 3-9.

52. Мамонтова, Е.А. Содержание стойких органических загрязнителей в грудном молоке жительниц Иркутской области / Е.А. Мамонтова, Е.Н. Тарасова, М.И. Кузьмин [и др.] // Гигиена и санитария. - 2010. - № 1. C. 35-38.

53. Мамонтова, Е.А. Эколого-гигиеническая оценка последствий загрязнения стойкими органическими соединениями промышленного города (на примере г. Усолье-Сибирское): II. Продукты питания, биосубстраты жителей, оценка рисков здоровью / Е.А. Мамонтова, Е.Н. Тарасова, А.А. Мамонтов // Экологическая химия. - 2017. - Т. 26. - № 1. - С. 41-52.

54. Павлов, А.В. Справочник по пестицидам: (Гигиена применения и токсикология) / под ред. А.В. Павлова. - Киев.: Урожай, 1986. - 431 с.

55. Международный проект по ликвидации СО3 - IPЕР. // [Электронный ресурс]. URL: https://ipen.org/sites/default/files/documents/1 rus_time_to_act_obsolete_pesticides-ru.pdf.

56. Мельников, Н.Н. Пестициды. Химия, технология, применение / Н.Н. Мельников. - М.: Книга по Требованию, 2013. - 697 с.

57. Мирзакулов, Д.С. Особенности влияния хлорогранических соединений и их метаболитов на состояние фертильности мужчин, проживающих в Орской области Кыргызстана / Д.С. Мирзакулов, А.А. Эшбаев, Ш.С. Мирзокулов, Р.К. Калматов // Современые проблемы науки и образования. - 2016. - № 3. - С. 66.

58. Московчук, О.Б. Корреляционные взаимосвязи показателей иммунного статуса родильниц с содержанием хлорорганических пестицидов в крови / О.Б. Московчук, К.М. Московчук, В.Ф. Демченко, Е.В. Евстафьева // Таврический медико-биологический вестник. - 2012. Т. 15. № 3. - С. 176-178.

59. Мошанский, В.Ф. Дифференциальная диагностика двух форм некроспермии / В.Ф. Мошанский, С.А. Каган, О.Л. Тектинский [и др.] // Урология и нефрология. - 1987. - № 4. - С. 57-59.

60. Мустафакулова, Н.И. Факторы риска развития и особенности клинического течения лейкозов в республике Таджикистан / Н.И. Мустафакулова, Т.И. Меликова, Н.С. Мустафакулова // Вестник Авиценны. 2015. - № 1. - С. 67-70. 
61. Никитин, А.И. Загрязнители биосферы и их влияние на репродуктивную функцию человека / А.И. Никитин // Биосфера. - 2009. - № 2. С. 218-229.

62. Никитин, А.И. Факторы среды и репродуктивная система человека (ответственность перед будущими поколениями) / А.И. Никитин. СПб.: ЭЛБИ-СПб, 2008. - 216 с.

63. Нуритдинова, Ф. Состояние органа зрения у лиц, с интоксикацией пестицидами, работающих в сельском хозяйстве Узбекистана: (Клиническое и экспериментальное исследование): автореф. дис. ... д-ра мед. наук / Ф. Нуритдинова. - Ташкент, 1974. - 29 с.

64. О мерах по обеспечению выполнения Российской Федерацией обязательств, предусмотренных Стокгольмской конвенцией о стойких органических загрязнителях от 22 мая 2001 г. (В редакции постановлений Правительства Российской Федерации от 13.05.2015 № 464, от 19.09.2016 № 946, от 20.11.2018 № 1391, от 11.02.2019 № 113).

65. Овчинникова, Е.Л. Мониторинг качества и безопасности пищевых продуктов как составная часть социально-гигиенического мониторинга / Е.Л. Овчинникова, Н.В. Резанова, А.В. Брусенцова // СибирьВосток. - 2003. - № 10. - С. 31-36.

66. Омарова, 3.М. Влияние пестицидов на здоровье детей. // Российский вестник перинатологии и педиатрии. - 2010. - № 1. - С. 59-64.

67. Оникиенко, Ф.А. Состояние некоторых сторон углеводного обмена и окислительных процессов при воздействии на организм отдельных хлорорганических инсектицидов: автореф. дис. ... канд. биол. наук / Ф.А. Оникиенко. - Киев, 1966. - 18 с.

68. Паизова, 3.М. Влияние загрязнения окружающей среды хлорорганическими пестицидами на развитие рака молочной железы у женщин, в зависимости от количества родов, в условиях юга Кыргызстана / 3.М. Паизова, Р.М. Тойчуев // Журнал научных статей «Здоровье и образование в XXI веке» (Серия медицина), - 2012. -Т. 14. - № 1. - С. 160.

69. Парамончик, В.М. Функциональное состояние печени у лиц, подвергающихся воздействию некоторых хлорорганических соединений в условиях их производства: автореф. дис. ...канд. мед. наук / В.М. Парамончик. - Киев, 1968. - 17 с.

70. Перхурова В.П. Исследование по токсикологии карбофоса и комбинированному действию промежуточных продуктов его производства: автореф. дис. ... канд. мед. наук / В.П. Перхурова. - Куйбышев, 1974. - 17 с. 
71. Приказ Госкомэкологии РФ от $13.04 .99 \mathrm{~N} 165$ «О рекомендациях для целей инвентаризации на территории Российской Федерации производств, оборудования, материалов, использующих или содержащих ПХБ, а также ПХБ-содержащих отходов».

72. Приказ от 23.02.99 № 76 «О проведении на территории Российской Федерации инвентаризации производств, оборудования, материалов, использующих или содержащих полихлорированные бифенилы (ПХБ), а также ПХБ-содержащие отходы». URL: https://base.garant.ru/2156961/.

73. Пуэрто, К.П. Уровни ДДТ и его метаболитов в биологической среде человека / К.П. Пуэрто, А.М.Д. Фернандес, А.М. Хименес [и др.] // Гигиена и санитария. - 1990. - № 10. - С. 73-75.

74. Ракитский, В.Н. Прогностический риск токсического воздействия пестицидов на здоровье работающих // Медицина труда и промышленная экология. - 2015. - № 10. - С. 5-17.

75. Ракитский, В.Н. Современные методические подходы в оценке мутагенности пестицидов / В.Н. Ракитский, Н.А. Илюшина, Ю.А. Ревазова // Гигиена и санитария. - 2017.- Т. 96 (11). - С. 1017-1020.

76. Ракитский, В.Н. Морфофункциональные критерии действия на организм факторов окружающей среды / В.Н. Ракитский, Н.И. Николаева. М.: Медицина, 2001. - 182 с.

77. Расулов, М.Т. Морфологическая и гистоэнзиматическая характеристика почек при хроническом воздействии пестицидов гексахлорциклогексана, хлорофоса и медного купороса / М.Т. Расулов, М.А. Шахназаров, А.М. Шахназаров, Б.Г. Магомедгаджиев // VII научно-практическая конференция памяти профессора С.А. Абусуева «Проблемы экологической медицины». - Махачкала: Дагестанский государственный медицинский университет, 2017. - С. 242-245.

78. Ревич, Б.А. Диоксины, фураны и ПХБ в крови подростков Чапаевска - первые результаты проспективного эпидемиологического исследования / Б.А. Ревич, О.В. Сергеев, Р. Хнузер // Токсикологический вестник. - 2006. - № 5(80). - С. 2-8.

79. Ревич, Б.А. Здоровье населения и загрязнение окружающей среды стойкими органическими загрязнителями / Б.А. Ревич, А.А. Шелепчиков // Гигиена и санитария. - 2008. - № 4. - С. 26-32.

80. Ревич, Б.А. Инновационные эколого-эпидемиологические технологии оценки влияния диоксинов на здоровье детей / Б.А. Ревич, 
О.В. Сергеев, А.А. Шелепчиков // Экология человека. - 2012. - № 8. C. 42-49.

81. Ревич, Б.А. СОЗ и оценки воздействия на здоровье населения: некоторые результаты работ в России / Б.А. Ревич, О.В. Сергеев, А.А. Шелепчиков // Сборник трудов IV токсикологического съезда токсикологов России. - 2013.

82. Ровинский, Ф.Я. Фоновый мониторинг загрязнения экосистем суши хлорорганическими соединениями / Ф.Я. Ровинский, Л.Д. Воронова, М.И. Афанасьев [и др.]. - Л.: Гидрометеоиздат, 1990. - 270 с.

83. Росивая, Л. Трансплацентарный переход пестицидов в человеческий эмбрион / Л. Росивая, А. Соколай [и др.] // Чехословацкая медицина. 1983. - № 1. - С. 1-7.

84. Рузыбакеев, Р.М. Иммунодефицитные состояния при хронических интоксикациях пестицидами и проблема их коррекции: (Клиникоэкспериментальное исследование): автореф. дис. ... д-ра. мед. наук / Р.М. Рузыбакеев. - Ташкент-Москва, 1987. - 32 с.

85. Сарайманова, 3.С. Влияние некоторых ядохимикатов на половую сферу (клинико-экспериментальное исследование): автореф. дис. ... канд. мед. наук. / 3.С. Сарайманова. - Ташкент, 1971. - 22 с.

86. Саттарова, С.Ш. Влияние некоторых пестицидов на половую систему, репродуктивную функцию, внутриутробное развитие, развитие плода и потомства: автореф. дис. ... канд. мед. наук / С.Ш. Саттарова. Ташкент, 1981. - 23 с.

87. Семеренко, С.А. Экология и защита растений // Масличные культуры / С.А. Семеренко // Научно-технический бюллетень Всероссийского научно-исследовательского института масличных культур. - 2015. № 4 (164). - С. 103-137.

88. Ситдыкова, М.Э. Влияние хлорорганических пестицидов на некоторые урологические заболевания / М.Э. Ситдыкова, С.А. Аллазов, Д.Р. Саяпова // Казанский медицинский журнал. - 2010. - Т. 91 - № 3. - С. 372-374.

89. Соленова, Л.Г. Факторы онкологического риска у детей и подходы к профилактике их воздействия / Л.Г. Соленова // Педиатрия. - 2011. T. 90. - № 4. - С. 120-126.

90. Сперанская, О. Стойкие органические загрязнители: обзор ситуации в России [Интернет]. Международный проект по ликвидации СО3 / O. Сперанская, О. Цитцер // [Электронный ресурс]. URL: www.ipen.org. 
91. Тадевосян, Н.С. Вопросы накопления и обнаружения некоторых стойких органических загрязнителей у сельских жителей Армении / Н.С. Тадевосян, А.Э. Тадевосян, А.Н Джанджапанян [и др.] // Вестник КазНМУ. - 2012. - № 3. - С. 212.

92. Тадевосян, Н.С. Мониторинг загрязнения окружающей среды в Армении и некоторые вопросы репродуктивного здоровья и цитогенетического статуса организма / Н.С. Тадевосян, С.А. Мурадян, А.Э. Тадевосян [и др.] // Гигиена и санитария. - 2012. - Т.91. - № 5. - С. 48-51.

93. Тер-Аванесов, Г.В. Проблемы репродуктивного здоровья мужчин: практическое руководство / Г.В. Тер-Аванесов. - М.: ООО «Тэлси», 2004. - $111 \mathrm{c}$.

94. Тойчуев, Р.М. Влияние содержания хлорорганических пестицидов в плаценте на течение беременности и роды у женщин / Р.М. Тойчуев // Гигиена и санитария. - 2015. - № 6. - С. 106-108.

95. Тойчуев, Р.М. Распространенность бесплодия у мужчин, проживающих в условиях загрязнения окружающей среды хлорорганическими пестицидами / Р.М. Тойчуев, Д.С. Мирзакулов, Т.Р. Пайзилдаев // Гигиена и санитария. - 2015. - № 6. - С. 99-101.

96. Ушаков, А.А. Гигиеническая оценка неблагоприятных социальных, санитарно-гигиенических факторов окружающей среды на территории Алтайскиго края / А.А. Ушаков, В.В. Турбинский, И.Г. Пащенко, А.С. Катунина // Анализ риска здоровью. - 2015. - № 4 (12). - С. 50-61.

97. Федеральная служба по гидрометеорологии и мониторингу окружающей среды (Росгидромет). Обзор состояния и загрязнения окружающей среды в Российской Федерации за 2018 год. - М: Росгидромет, 2019. - 225 с.

98. Федоров, Л.А. Пестициды - токсический удар по биосфере и человеку / Л.А. Федоров, А.В. Яблоков. - М.: Наука, 1999. - 461 с.

99. Хаитов, Р.М. Экологическая иммунология / Р.М. Хаитов, Б.В. Пинегин, Х.И. Истамов. - М.: Изд-во ВНИРО, 1995. - 218 с.

100. Хакимов А.М. Состояние вестибулярного анализатора у работающих с хлорорганическими и фосфорорганическими пестицидами: (Клиническое и экспериментальное исследование): автореф. дис. ... канд. мед. наук / А.М. Хакимов. - Ташкент, 1975. - 24 с.

101. Хамидов, М.Х. Детородная функция, исход беременности и родов для плода и новорожденного у женщин, занятых выращиванием и 
возделыванием хлопчатника: автореф. дис. ... д-ра мед. наук / М.Х. Хамидов. - Самарканд, 1986. - 46 с.

102. Хамитова, Р.Я. Заболеваемость населения в условиях длительного применения пестицидов / Р.Я. Хамитова, Г.Т. Мирсаитова // Здравоохранение Российской Федерации. - 2014. - Т. 58. - № 1. - С. 38-42.

103. Худолей В.В. Экологически опасные факторы / В.В. Худолей, И.В. Мизгирев. - СПб.: Publishing House, 1996. - 111 с.

104. Цыганков, В.Ю. Химические и экологические аспекты стойких органических загрязняющих веществ: учебное пособие / В.Ю. Цыганков, М.Д. Боярова, О.Н. Лукьянова. - Владивосток, 2015. - 103 с.

105. Черных, А.М. Угрозы здоровью человека при использовании пестицидов (Обзор) / А.М. Черных // Гигиена и санитария. - 2003. - № 5. С. 25-28.

106. Шафеев, М.Ш. Влияние некоторых пестицидов и их комбинаций на показатели иммунитета и неспецифической реактивности организма: автореф. дис. ... канд. мед. наук / М.Ш. Шафеев. - Казань, 1978. - 20 с.

107. Шицкова, А.П. Гигиеническая оценка кардиотоксического действия некоторых пестицидов / А.П. Шицкова, Н.И. Николаева, И.Д. Гадалина // Гигиена и санитария. - 1986. - № 6. - С. 4-7.

108. Шумейко, А.Я. Экологическая оценка взаимодействия пестицидов и радиации в агроэкосистемах Брянской области: автореферат дис. ... канд. сельскохоз. наук / А.Я. Шумейко. - Брянск, 2004. - 22 с.

109. Шушпанов, А.Г. Влияние запрещенных к применению пестицидов на здоровье человека / А.Г. Шушпанов // Технология и товароведение инновационных пищевых продуктов. - 2011. - № 6 (11) - С. 73-77.

110. Юдаев, А.И. Полихлорированные бифенилы и диоксины - суперэкотоксиканты XXI века / А.И. Юдаев // Энергия: экономика, техника, экология. - 2010. - № 1. - С. 60-65.

111. Юсупова Ф.Д. Вопросы гигиены труда и ранние клиникофункциональные и биохимические изменения кожи при воздействии некоторых пестицидов: автореф. дис. ... канд. мед. наук / Ф.Д. Юсупова. Ташкент, 1988. - 17 с.

112. AMAP Assessment 2002: Persistent organic pollutants in the Arctic. - Norway, Oslo: AMAP, 2004.

113. AMAP Assessment 2015: Human Health in the Arctic. - Oslo: AMAP, 2015. 
114. Barr, D.B. Strategies for biological monitoring of exposure for contemporary use pesticides / D.B. Barr, J.R. Barr, W.J. Driskell [et al.] // Toxicology and Industrial Health. - 1999. - V. 15. - P. 168-79.

115. Burns, J. Association Between Chlorinated Pesticides in the Serum of Prepubertal Russian Boys and Longitudinal Biomarkers of Metabolic Function / J. Burns, P. Williams, S. Korrick [et al.] // American Journal of Epidemiology. - 2014. - V. 180. - P. 909-919.

116. Dudarev, A.A. Public health practice report: water supply and sanitation in Chukotka and Yakutia, Russian arctic // International Journal of Circumpolar Health. - 2018. V. 77. - No. 1. - P. 1423826.

117. Ginsberg, G. Incorporating pharmacokinetic differences between children and adults in assessing children's risks to environmental toxicants / G. Ginsberg, D. Hattis, B. Sonawane // Toxicology and Applied Pharmacology. - 2004. - V. 198. - No. 2. - P. 164-183.

118. Krauthacker, B. Organochlorine pesticides and PCBs in human milk collected from mothers nursing hospitalized children / B. Krauthacker, E. Reiner, A. Votava-Raić [et al.] // Chemosphere. -1998. - V. 37. - No. 1. P. 27-32.

119. Le Phuoc Cuong. Экомониторинг пестицидов в волосах вьетнамцев, проживающих в г. Дананг (Вьетнам) и в г. Казань / Le Phuoc Cuong, М.И. Евгеньев, Ф.М. Гумеров [и др]. // Вестник казанского технологического университета. - 2011. - №18. - С. 31-37.

120. Lukyanova, O.N. Pacific salmon as a vector in the trasnsfer of persistent organic pollutants in the ocean / O.N. Lukyanova, V.Yu. Tsygankov, M.D. Boyarova, N.K. Khristoforova // Journal of Ichthyology. - 2015. - V. 55. No. 3. P. 425-429.

121. Lukyanova, O.N. Pesticide biotransport by Pacific salmon in the northwestern Pacific Ocean / O.N. Lukyanova, V.Yu. Tsygankov, M.D. Boyarova, N.K. Khristoforova // Doklady Biological Sciences. - 2014. V. 456. - No. 1. - P. 188-190.

122. Polder, A. Spatial and temporal changes of chlorinated pesticides, PCBs, dioxins (PCDDs/PCDFs) and brominated flame retardants in human breast milk from northern Russia / A. Polder, G.W. Gabrielsen, J.Ø. Odland [et al.] // Science of the Total Environment. - 2008. - V. 391. - P. 41-54.

123. Ruder, A.M. Gliomas and farm pesticide exposure in men: the upper midwest health study / A.M. Ruder, M.A. Waters, M.A. Butler [et al.] // 
Archives of Environmental Health: An International Journal. - 2004. - V. 59. No. 12. - P.650-657.

124. Saleh, M.A. Breast Milk as a Biomarker for Monitoring Human Exposure to Environmental Pollutants / M.A. Saleh, A.M. Afify, A. Ragab [et al.]. - In: Biomarkers for Agrochemicals and Toxic Substances, American Chemical Society. - 1996. - P. 114-125.

125. Sergeyev, O. POPs in human milk in Chapaevsk, Russia, five years following cessation of chemical manufacturing and decade of remediation program, pilot study / O. Sergeyev, A. Shelepchikov, T. Denisova [et al.] // Organohalogen Compounds. - 2008. - V. 7. - P. 1946-1949.

126. Stockholm Convention on Persistent Organic Pollutants (Text and Annexes) [Internet]. UNEP; 2001. URL: http://chm.pops.int/

127. Tsydenova, O.V. Organohalogen Compounds in Human Breast Milk from Republic of Buryatia, Russia / O.V. Tsydenova, A. Sudaryanto, N. Kajiwara [et al.] // Environmental Pollution. - 2007. - V. 46. - P. 225-235.

128. Tsygankov, V.Yu. Bioaccumulation of POPs in human breast milk from south of the Russian Far East and exposure risk to breastfed infants / V.Yu. Tsygankov, Y.P. Gumovskaya, A.N. Gumovskiy [et al.] // Environmental Science and Pollution Research. - 2020. - V. 27. - P. 5951-5957.

129. Tsygankov, V.Yu. Bioindicators of Organochlorine Pesticides in the Sea of Okhotsk and the Western Bering Sea / V.Yu. Tsygankov, M.D. Boyarova, O.N. Lukyanova, N.K. Khristoforova //Archives of Environmental Contamination and Toxicology. - 2017. - V. 73. - No. 2. - P. 176-184.

130. Tsygankov, V.Yu. Hexachlorocyclohexane $(\mathrm{HCH})$ in human blood in the south of the Russian Far East / V.Yu. Tsygankov, M.D. Boyarova, P.F. Kiku, M.V. Yarygina // Environmental Science and Pollution Research. - 2015. V. 22. - P. 14379-14382.

131. Tsygankov, V.Yu. Organochlorine pesticides in marine ecosystems of the Far Eastern Seas of Russia (2000-2017) / V.Yu. Tsygankov // Water Research. - 2019. V. 161. - P.43-53.

132. Tsygankov, V.Yu. Selected Organochlorines in Human Blood and Urine in the South of the Russian Far East / V.Yu. Tsygankov, N.K. Khristoforova, O.N. Lukyanova [et al.] // Bulletin of Environmental Contamination and Toxicology. - 2017. - V.99. - P.460-464.

133. Tsygankov, V.Yu. Trace concentrations of organochlorine compounds in biological liquids of the Russian Far East residents / 
V.Yu. Tsygankov, M.V. Yarygina, O.N. Lukyanova [et al.] // Ekologiya Cheloveka (Human Ecology). - 2019. - V. 1. - P. 15-19.

134. Yufit, S. Contamination of human milk with PCDDs, PCDFs and PCBs in two Russian cities / S. Yufit, R. van Leeuwen, R. Malisch, D.P. Samsonov // Organohalogen Compounds. - 2002. - V. 56. - P. 333-336. 